\title{
Action Verb Nosi `Cooking in Bima Language: A Study of Natural Semantic Metalanguage
}

\author{
Rabiyatul Adawiyah \\ Udayana University, Denpasar, Indonesia \\ I Nengah Sudipa \\ Udayana University, Denpasar, Indonesia \\ Made Sri Satyawati \\ Udayana University, Denpasar, Indonesia \\ I Made Rajeg \\ Udayana University, Denpasar, Indonesia
}

\begin{abstract}
There are two subordinate structures in action verbs, namely uncompositional polysemy. Action verbs to do and happen are action verbs with uncomposed polysemy, including Cooking Nose. This research aims to find out the mapping and explication of the 'cooking' action verb. The method used is qualitative. The data source consists of oral data taken from key informants, written data collected from storybooks in the Bima language and language intuition. The technique used is interview and literature study. The data collection method is advanced, namely the agih method with the application of transformation and insertion techniques used to reveal the original meaning contained in BBM. The default meaning is used to determine the semantic structure of $\mathrm{VBBm}$ by explication or paraphrasing techniques. Each verb nosi cooking is based on: the tool, the model of movement, the part of the entity that is being treated, the result that the agent wants to achieve. The results show that the Bima language action verb 'Cooking' in general has a component mapping ' $X$ Doing something to $Y$ ' and therefore 'Something happened to $Y$ '. A number of words that contain the meaning of cooking: lowi, mbako, $\underline{d} a n d a$, salunga, puru, sanggowo, sanggapi, suje, ncango, and tumi, gule. This variant has unique semantic characteristics so that the meaning content of each word is different even though it is still in the same field of meaning (Cf. Adawiyah, 2021).
\end{abstract}

Index Terms - action verbs, cooking, natural semantic metalanguage

\section{INTRODUCTION}

Each regional language has its uniqueness and potential that needs to be explored more deeply, one of which is the Bima language. The Bima language is spoken by the Bima Tribe on the East Sumbawa Island, West Nusa Tenggara, and is used by its speakers as a means of communication both within the family and in the community. The Bima language as Indonesian has a semantic structure, namely verbs and nouns. Leech (1981) states that verbs are the central element because they can determine the structure of a sentence. The meaning of a verb in a proposition varies, depending on its relation to the argument, with the various meanings of the verb (Ola, 2021), so the meaning discussed in this study is focused on the conceptual meaning (Adawiyah, 2021).

Moreover, Adawiyah (2021) states that verbs in the Bima language still have many semantic features that need to be studied and developed with various theories. BBm verbs are grouped based on time stability scales. Based on the time stability scale, VBBm is classified into three: state verbs, process verbs and action verbs. This study is more devoted to action verbs. Action verbs are not time stable, for example, weli `buy', lao `go`, rai `run', nono `drink', ngaha `eat'. In the Bima language, there are 34 letters; a, b, b, c, d, d, e, f, g, h, i, j, k, l, m, mb, mp, n, nc, nd, ng, gg, nt, o, p, q, r, s, t, u, v, w, y, and z. (Alwi, 2003; Adawiyah, 2021).

The verbs discussed in this paper are Action verbs with the word Interesting because they have specific semantic features and characteristics. How to find out the meaning? Only with the help of metalanguage theory can we understand it. The description of the theory will be described in the theoretical study section. Based on this description, it can be stated here that the fundamental reasons behind the urgency of this research, namely (1) A lot of wealth or features owned by BBM. (2) It has not been studied or analyzed in more depth so that the Natural Semantic Metalanguage theory can bridge this problem with mapping and explication analysis (Adawiyah, 2021).

\section{LITERATURE REVIEW}

\section{A. Natural Semantic Metalanguage Theory}


This study uses the theory of Natural Semantic Metalanguage. There are three reasons why this theory was chosen. (i) Natural Semantic Metalanguage theory is designed and used to exclude all lexical, illocutionary, and grammatical meanings. This theory can, of course, be used to explain the meaning of a verb. (ii) proponents of the Natural Semantic Metalanguage theory believe in the principle that the natural condition of a language is to maintain one form for one meaning and one meaning for one form. This principle is not only applied to grammatical constructions but also words. (iii) in the theory of Natural Semantic Metalanguage, the meaning explication is framed in a metalanguage, which comes from natural language. This explication can be understood by all native speakers of the language concerned. Goddard and Wierzbicka, (2014) argues that Natural Semantic Metalanguage examines the minor components of every language, which consists of 65 semantic primes and more than 50 universal semantic molecules, as shown in the table below.

TABLE 1

DEFAUlt MEANING DEVICE

\begin{tabular}{|c|c|c|}
\hline No & Component & Semantic Element \\
\hline 1 & Substantives & $\begin{array}{l}\text { I-ME, YOU, SOMEONE, PEOPLE, SOMETHING/THING, } \\
\text { BODY }\end{array}$ \\
\hline 2 & Relational Substantives & KIND OF PART \\
\hline 3 & Determiners & THIS, THE SAME, OTHER-ELSE-ANOTHER \\
\hline 4 & Quantifiers & $O N E, T W O, S O M E, A L L, M U C H / M A N Y, L I T T L E / F E W$ \\
\hline 5 & Evaluators & $G O O D, B A D$ \\
\hline 6 & Descriptors & $B I G, S M A L L$ \\
\hline 7 & Mental predicates & THINK, KNOW, WANT, DON'T WANT, FEEL, SEE, HEAR \\
\hline 8 & Speech & SAY, WORDS, TRUE \\
\hline 9 & Action, Events, Movement, Contact & DO, HAPPEN, MOVE, TOUCH \\
\hline 10 & $\begin{array}{l}\text { Location, } \\
\text { Specification }\end{array}$ & $\begin{array}{l}\text { BE (SOMEWHERE), THERE } \\
\text { (SOMEONE/SOMETHING) }\end{array}$ \\
\hline 11 & Life and Death & LIVE, DIE \\
\hline 12 & Time & $\begin{array}{l}\text { WHEN/TIME, NOW, BEFORE, AFTER, A LONG TIME, A } \\
\text { SHORT TIME, FOR SOME TIME, MOMENT }\end{array}$ \\
\hline 13 & Space & $\begin{array}{l}\text { WHERE/PLACE, HERE, ABOVE, BELOW, FAR, } \\
\text { NEAR, SIDE, INSIDE, TOUCH (CONTACT) }\end{array}$ \\
\hline 14 & Logical Concepts & NOT, MAYBE, CAN, BECAUSE, IF \\
\hline 15 & Intensifier, Augmentator & VERY, MORE \\
\hline 16 & Similarity & LIKE/US/WAY \\
\hline
\end{tabular}

Wierzbicka claims that the set of 'original meaning' above is universal because it reflects the essential human mind regardless of the level and level of culture possessed by each nation. Wierzbicka began to emphasize that he was looking for a mini-lexicon and a complete mini-language for semantic analysis. The 'default meaning' consisting of lexicon items should have a universal syntactic pattern that can and must be determined. The term 'natural meaning of metalanguage' was adopted to reflect this. Thus, the term 'natural meaning of metalanguage' that is used can be interpreted as a mini-language formed by lexicon and syntax that comes from natural language because it comes from natural language (Adawiyah, 2021).

\section{B. Semantic Structure}

The formation of the semantic structure is related to the semantic component, and this component determines the structure of language birth. Tampubolon (1979) argues that the process of its formation is considered a description of the mental process of the speaker-hearer so that the process is called universal. In line with that, Weinreich (1966) says that the syntactic structure is a pattern for semantic components so that the semantic structure has the types of categories and syntactic relations found in natural language syntax (Allan, 1998).

Cross-language, if the meaning of a language corresponds one to one with the meaning of another language, the two languages are semantically considered isomorphic or have the same semantic structure (Latupeirissa, 2016; 2019; 2020). However, it should be realized that the degree of isomorphism between languages is not the same. This is because the vocabulary structure reflects the cultural peculiarities of the people who use that language. Therefore, all meanings in a language are unique and do not apply or relate to other languages. Wierzbicka (1996) also argues that each element has a unique network in a language and occupies a special place in that network. According to him, it is difficult to find the same network of relationships by comparing two or more languages. What can be expected is the discovery of a related set of 'default meanings'. Furthermore, if a word is compared with other words, which are intuitively felt to be related, the word's true meaning can be found. Even if the comparison is made correctly so that each distinct element can be identified, two possibilities will be encountered, namely (1) finding symmetry and regularity in the semantic structure or (2) finding irregularities in the network of elements.

\section{ReSEARCH METHODOLOGY}

This research is qualitative type. Sources of data were taken from oral data collected through interviews with key informants. Researchers involved direct contact with key informants. Conduct interviews and record fuel data used by 
the Bima community directly in the field. When conducting interviews, researchers used tools, such as a list of questions about cooking verb fuel and an explanation of the answers to these questions was recorded manually (Cf. Adawiyah, 2021).

\section{A. Sample and Participants}

The research location is in Parado District, consisting of 5 villages (Parado Rato Village, Parado Wane, Kanca, Kuta and Lere), Bima Regency, West Nusa Tenggara. The participants are key informants who understand Bima language action verbs, religious leaders, regional language teachers, and religious teachers (Spradley, 1980).

\section{B. Instruments}

The list of words has verb types, subtypes, and sub-types that refer to the universal default lexicon (see appendix). This list is sequentially asked using a structured interview technique to obtain information wholly and systematically. The advantage obtained from interviews with several informants shows that the same data can be cross-checked among the informants to make the results more convincing. This can be used as a means of verification or testing to determine whether the meaning of a lexicon is specific or universal. Apart from the above data collection methods, a participatory approach was also used. The participatory approach is carried out with researchers being directly involved in the event of the language of the BBM community speakers and bringing a list of questions to be verified by key informants. In addition to this, literature studies and documentation studies are also used (Adawiyah, 2021).

\section{Data Collection and Analysis}

The method used to collect data is the proficient method (Bungin, 2003; Merriam, 2009). The data collected follows the research objectives. The descriptive method used as a qualitative research paradigm is based on converting, inserting paraphrase and parsing (Cf. Oeinada et al., 2021). The Agih method with the application of transformation and insertion techniques is used to reveal the original meaning of BBM. The default meaning is used to determine the semantic structure of VBBm by explication or paraphrase technique (Adawiyah, 2021).

\section{RESULT AND DiSCUSSION}

Based on the methods and means used in Cooking, these verbs are divided into several groups, namely (1) "Cooking" with water: lowi, mbako, danda, salunga (2) "Cooking" utilizing fire: puru, sanggowo, respond, suje, kato, (3) "Cooking" with oil and without oil: nango, and tumi, gule.

\section{A. By Means of Water: Lowi, Mbako, Danda, Salunga}

(4-1) Ahma, lowi ja pu kalo ese meja re, Ahmad, please boil the bananas on the table, wa u nggori ede lowi wali uta mbeca it's done, boil the vegetables again 'Ahmad, please boil the bananas on the table, then cook the vegetables

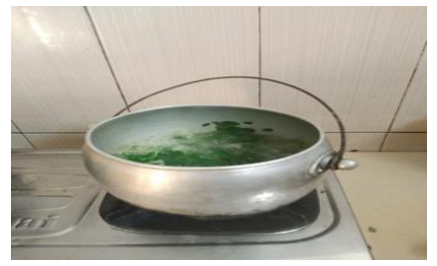

Activity lowi' boiling' is the activity of cooking food ingredients, bananas in hot water in a moment. Non-animate entities that can be subject to this activity are bananas, spinach, kale, bean sprouts, and long beans, used as food such as urab and a mixture of lawar. By immersing the vegetables in boiling water for a matter of seconds, the vegetables are said to be cooked. This activity may or may not take longer and the entity can be in the form of various types of food ingredients, such as bananas (certain fruits), tubers, eggs, ketupat/lontong, meat, and certain vegetables. The cooking method is usually done by cooking the food ingredients before the water boils until the water boils, and in a matter of minutes, the food ingredients can be said to be cooked.

(4-2) Mbako ja pu bongi dei wonca, loku ra ngaha

Please cook rice in the gerabag, so you can eat

sama labo kaluarga ma mai pede si

the same as the family who will come later

Cook rice in kula, so we can eat with family who come 


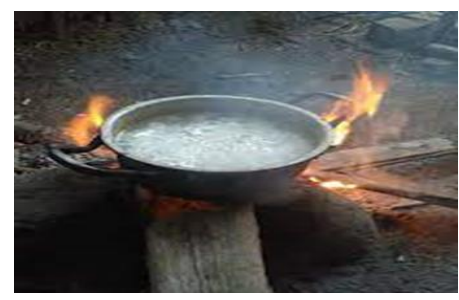

(4-3) Lowi ulu toge, bue di ndawi kai lada

Boil the sprouts, long beans to make urab

Boiled vegetables first if you want to make urab

At that time, $\mathrm{X}$ did something to $\mathrm{Y}$

Because of this, at the same time, something happened to $Y$

$\mathrm{X}$ does this with something (means: water, fire, and a pot)

$\mathrm{Y}$ is ripe (boiled). $\mathrm{X}$ wants this

$\mathrm{X}$ did something like this

(4-4) Aina nefa danda oha bai da

Do not forget to dress the rice, so it doesn't

ngenta na, ma`alumu sato $i$ oina

raw know a little water

Do not forget to cook the uncooked rice, because the water is a little.

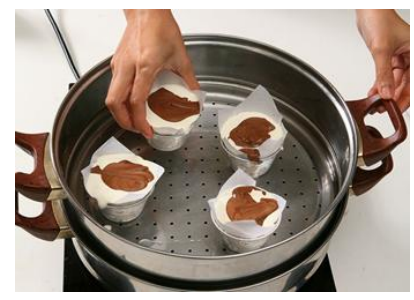

Cooking activities by steaming are carried out using a steamer (cone-shaped woven), a cork, cubluk or pot equipped with a filter inside that cooks rice with hot water vapor under the nest. Non-animate entities that can be subject to this work are rice, sticky rice, tubers, and several bananas and vegetables. This cooking activity works by inserting the food ingredients into the steamer, then placing it on a pot or pan filled with water. In a matter of minutes, the entity can be said to be mature.

Explication

At that time, $\mathrm{X}$ did something to $\mathrm{Y}$

Because of this at the same time, something happened to $Y$

$\mathrm{X}$ does this with something (means: water, fire, saucepan, pot, and steamer)

$\mathrm{Y}$ is ripe (steamed) $\mathrm{X}$ wants this

$\mathrm{X}$ did something like this

(4-5) Dou ma do`a naisi re, aina nefa salunga mena oha mu,

Person pray tomorrow do not forget to cook rice

'Tomorrow there is a prayer, do not forget to cormorant the rice

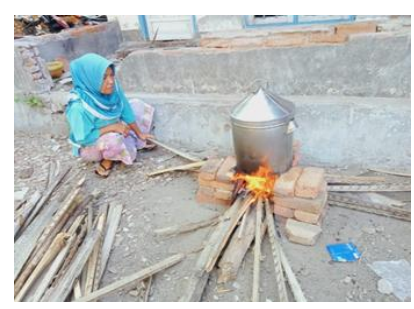

The lexicon of mbako, danda, salunga and lowi is doing activities with rice as the main entity included in the nonanimate entity, then after a while, the entity will turn into rice so that it can be said to be mature. These actions occur assisted utilizing water and fire as well as pots or pots as tools. In general, someone does this activity intentionally and consciously by mapping the "X" component wants this", and someone expects good (mature) results. As a result of this activity ", something good happened to $\mathrm{Y}$ ". The end of this activity is marked by a change in entity ' $\mathrm{Y}$ ' so that ' $\mathrm{X}$ ' wants this.

Explication

At that time, $\mathrm{X}$ did something to $\mathrm{Y}$ 
Because of this, at the same time, something happened to $\mathrm{Y}$

$\mathrm{X}$ does this with something (means: water, fire, and a pot)

$\mathrm{Y}$ is getting cooked (rice). $\mathrm{X}$ wants this

$\mathrm{X}$ did something like this

\section{B. By Means of Fire: Puru, Sanggowo, Sanggapi, Suje, Kato}

To "cook" this second represents the corpus of transitive verbs the prototype of intent as the primary means of fire. lexiconpuru, sanggowo, sanggapi, suje 'burn' describes a semantic structure with subcomponents " $\mathrm{X}$ does something to Y", "something good happens" and at the same time, something happens to Y", X does something", "something good happens". The following describes the method of "cooking" with fire.

(4-6) Puru wa`u pu ni u re, lokura caruna in the issue

Burn first this coconut, so it's good for shampooing

First, burn the coconut so that it is good for shampooing

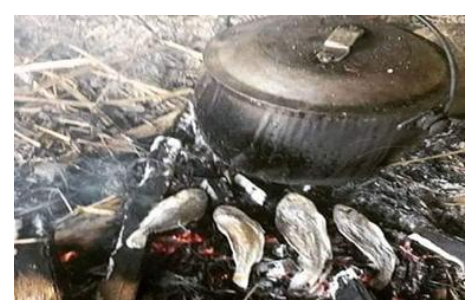

(4-7) Sanggowo ja pu uta aka

Burn the fish please

'Please burn the fish`

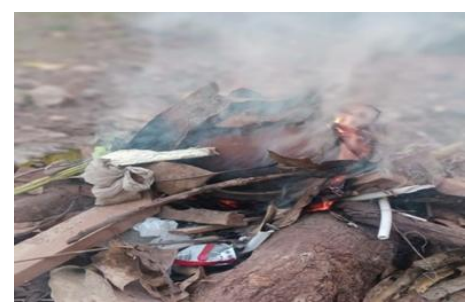

Cooking activities in this way use fire as the primary means. With the help of the heat of the fire, the food ingredients cooked in this way will be cooked. Non-animate entities subject to this work can be fish, tubers, and other cooking ingredients. This activity is done by bringing the food ingredients closer to the fire and in a matter of minutes the texture of the food ingredients will change and become cooked. The Sanggowo lexicon cooks using a pot made of earth, without using water.

Explication

At the time,

$\mathrm{X}$ did something to $\mathrm{Y}$

Because of this at the same time, something happened to $\mathrm{Y}$

$\mathrm{X}$ does this with something (means of fire) $\mathrm{Y}$ gets ripe (burns)

$\mathrm{X}$ wants this

$\mathrm{X}$ did something like this

From the data said puru, sanggowo, sanggapi, suje is done using firewood or dry coconut husk. The facilities are burned until they become coals, on top of the coals, then the activity is ready to be carried out. Non-animate entities that can be subject to this work can be fish, meat, or animals such as buffalo, cows and goats. This activity will change the texture of the entity's form, in a sufficient amount of time based on the type of entity, food ingredients cooked in this way can be said to be cooked. There is a slight difference with the kato lexicon, which lies in the use of banana leaves on burnt entities such as kato uta `fish pepes`. Rice paste, etc.

Explication

At that time, $\mathrm{X}$ did something to $\mathrm{Y}$

Because of this at the same time, something happened to $\mathrm{Y}$

$\mathrm{X}$ does this with something (means of embers)

$\mathrm{Y}$ is ripe (toasted) $\mathrm{X}$ wants this

$\mathrm{X}$ does something like this. 


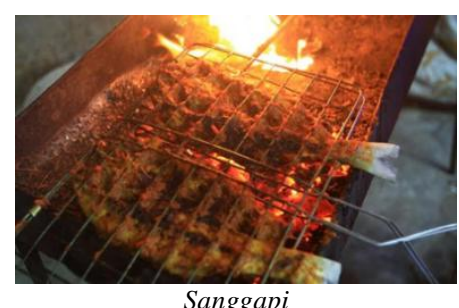

Sanggapi
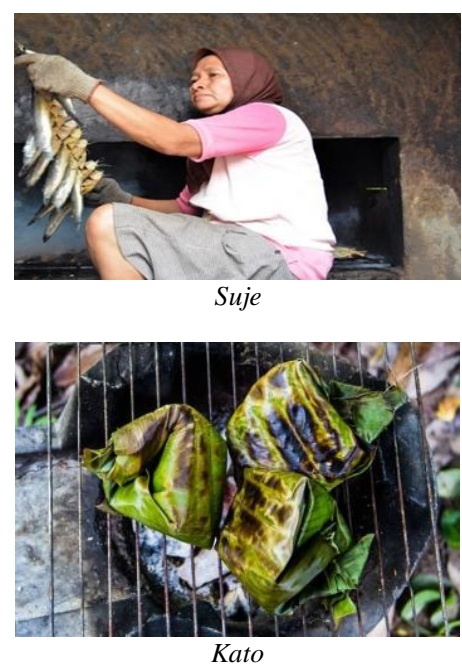

Lexicon puru, $k a^{\prime} a$ (burning food in coals)

(4-8) Jago ka`a pu aka kama`a, loku ra caru mami na

Corn burnt in coals, so that they are cooked well

'Bananas are burned in coals to make them tastier'

(4-9) Ka`a pu masaki re, loku ra raso na sarei re

Burn trash, to clean the yard

'Please burn the garbage in the yard to keep the yard clean`

Cooking activities with the term puru, $k a^{\prime} a$ this is also done using coals, butthe entity used is put into the embers. Non-animate entities subjected to this work can be several types of bananas, eggs, and tubers. The entity is cooked this way takes a few minutes. Then it can be cooked.

Explication

At that time, $\mathrm{X}$ did something to $\mathrm{Y}$

Because of this, at the same time, something happened to $Y$

$\mathrm{X}$ does this with something (means of embers)

$\mathrm{Y}$ is ripe (metabus) $\mathrm{X}$ wants this

$\mathrm{X}$ does something like this.

\section{With Oil and without Oil Means: Ncango, Tumi, Gule}

To "cook", the third represents the corpus of transitive verbs the prototype means as the main means with oil and without oil. Lexicon ncango, tumi, gule 'frying' describes a semantic structure with subcomponents "X does something to Y", "something good happens" and at the same time, something happens to Y", X does something", "something good happens". The following describes the method of "cooking" with oil and without oil. ncango, tumi, gule 'frying'.

Describing cooking activities using coconut oil as the main ingredient is generally referred to as 'frying'. Likewise in the Bima language. This activity is done by heating cooking oil (coconut oil) in a frying pan, then putting the entity into the hot oil, then within a few minutes, the entity will turn crispy and can be said to be cooked. Non-animate entities that are subject to this work are in the form of pre-dried food ingredients such as crackers, nuts, salted fish, and several other food ingredients that do not need to be dried before frying.

Tumi Explication

At that time, $\mathrm{X}$ did something to $\mathrm{Y}$

Because of this at the same time, something happened to $Y$

$\mathrm{X}$ did this with something (means of cooking oil)

$\mathrm{Y}$ is getting cooked (fried) $\mathrm{X}$ wants this 


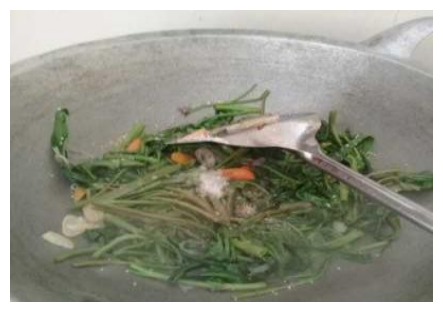

Cooking with this method uses only the heat of the pot and stirs the entity until it changes color and becomes dry. After all parts of the entity are dry, the entity will undergo further processing before being consumed. Non-animate entities subject to this work are in the form of seeds or nuts, such as coffee beans, belinjo beans, etc.

Ncango Explication

At that time, $\mathrm{X}$ did something to $\mathrm{Y}$

Because of this at the same time, something happened to $Y$

$\mathrm{X}$ does this with something (heated pot or pan)

$\mathrm{Y}$ goes dry (roasts) $\mathrm{X}$ wants this

$\mathrm{X}$ does something like this.

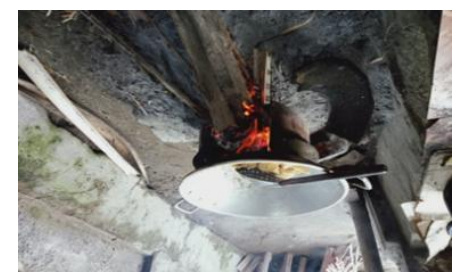

Cooking gule, this method uses the heat of a pot and stirs the ingredients like cooking spices until they change color and don't dry out. After all parts of the entity are cooked and fragrant, the entity will undergo the next process, which is to enter ingredients such as meat. Animate entities that are subject to this work are in the form of animal meat such as krbau, beef, horse or goat. After the entity is cooked, it is immediately served to eat

\section{Gule Explication}

At that time, $\mathrm{X}$ did something to $\mathrm{Y}$

Because of this at the same time, something happened to $Y$

$\mathrm{X}$ does this with something (heated pot or pan)

$\mathrm{Y}$ doesn't get dry, or half cooked until it smells good $\mathrm{X}$ wants this

$\mathrm{X}$ does something like this.

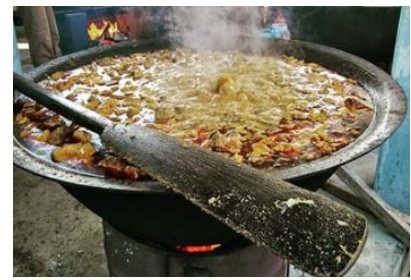

\section{CONCLUSION}

Verbs Action discusses the semantic structure of the Bima language, explicitly dealing with the original meaning of doing 'to do'. Two non-compositional polysemes are representing Doing are (i) Doing and Occurring and (ii) Doing and Moving. Cooking verbs are included in the uncomposed polysemy of Doing and Happening. The verb noci Cooking is based on: the tool, the model of movement, the part of the entity being treated, the result the agent wants to achieve. The results show that the Bima language action verb 'Cooking' in general has a component mapping ' $\mathrm{X}$ Doing something to $\mathrm{Y}$ ' and therefore 'Something happened to $\mathrm{Y}$ '. Based on the methods and means used in cooking, these verbs are divided into several groups, namely (1) "cooking" with water: lowi, mbako, danda, salunga (2) "cooking" with fire: puru, sanggowo, s Responsi, sujee, (3) "Cooking" with oil and without oil: ncango, and tumi, gule. This variant has unique semantic characteristics so that the meaning content of each lexicon is different even though it is still in the same field of meaning (Cf. Adawiyah, 2021).

\section{ACKNOWLEDGEMENTS}

The authors wish to thank the publisher for reviewing and accepting this paper and the suggestions from Prof. I Nengah Sudipa, Dr Sri Satyawati, and Dr I Made Rajeg. 


\section{REFERENCES}

[1] Adawiyah, R. (2021). Action Verbs with Notions of Hitting in Bima Language: The Study of Natural Semantics Metalanguage. The International Journal of Language and Cultural (TIJOLAC), 3(01), pp.56-65.

[2] Allan, Keith. (1986). Linguistic Meaning. Vol. 1. London: Routledge \& Kegan Paul.

[3] Alwi, Hasan. (2003). Indonesian Standard Grammar. Jakarta: Balai Pustaka.

[4] Bungin, Burhan. (2003). Data Analysis Qualitative Research, Philosophical and Methodological Understanding towards Mastery of the Application Model. Jakarta: Raja Grafindo Persada.

[5] Goddard, Cliff dan Anna Wierzbicka. (2014). Words and Meaning Lexical Semantics across Domains, Languages \& Cultures. Oxford: Oxford University Press.

[6] Latupeirissa, D. S. (2016). How to map the meaning of 'See'in Kupang Malay. Journal of Language and Culture, 6(1), 1-8.

[7] Latupeirissa, D.S. (2019). Naturalness of verbs in Kupang Malay language. Linguistics and Culture Review, 3(1), pp.60-69. https://doi.org/10.37028/lingcure.v3n1.12

[8] Latupeirissa, D. S. (2020). Documenting Languages Using Natural Semantic Metalanguage Theory: A Case Study of 'See'and 'Fall'in Kupang Malay Language. International Journal of Linguistics and Discourse Analytics, 1(2), 46-58. https://doi.org/10.52232/ijolida.v1i2.23

[9] Leech, Geoffrey. (1981). Semantics. England: Penguin Books.

[10] Merriam, Sharan. B. (2009). Qualitative Research: A Guide to Design and Implementation. San Francisco: Jossy-Bass.

[11] Oeinada, I.G., Beratha, N.L.S., Sudipa, I.N. and Satyawati, M.S. (2021). The Use of Japanese Synonymous Verbs GIVE: A Corpus-based Study. The International Journal of Social Sciences World (TIJOSSW), 3(01), pp.15-23.

[12] Ola, S.S. (2021). Culture of Mata Musan in Matrilineal Marriage System at Indigenous Community in Malaca-East Nusa Tenggara, Indonesia. The International Journal of Language and Cultural (TIJOLAC), 3(2), pp.64-71.

[13] Spradley, James P. (1980). Participant Observation. USA: Holt Rinehart and Winston.

[14] Tampubolon, D.P., Abubakar, Sitorus, M. (1979). Semantic Types of Contemporary Indonesian Verbs. Jakarta: Center for Language Development and Development.

[15] Weinreich, Uriel. (1998). Languages In Contact: Findings And Problems. New York: The Hague, Mouton.

[16] Wierbicka, A. (1996). Semantics: Primes and Universals. Oxford: Oxford University Press.

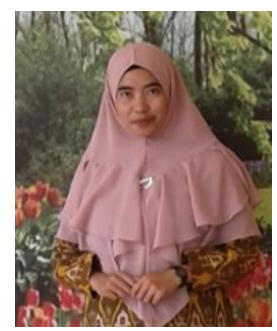

Rabiyatul Adawiyah was born in Parado Rato, Bima, 1985. She is currently a doctoral student studying at Udayana University, Bali, Indonesia. She accomplished her master's degree in 2012 from Mataram University, majoring in Indonesian Language Education. Her interest is in semantics, Language and literature. Currently, the author is a member of various memberships, such as Innovation NTB, Hiski NTB (Association of Indonesian Literature Scholars), IKAPROBSI (Indonesian Language and Literature Studies Societies) and ADOBSI (Indonesian Language and Literature Lecturers Association). She, currently, is a lecturer at Nahdlatul Wathan Mataram University.

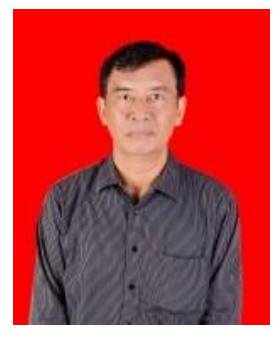

I Nengah Sudipa was born in Pesangkan Duda Timur, Selat, Karangasem, Bali, 31 July 1954. He graduated from the Department of English Language and Literature Udayana University, Denpasar, Indonesia (1981), Master of Arts (MA) from Linguistics Department of Monash University-Melbourne Australia (1988), Doctoral degree (S3) obtained at the Linguistics Program Studies, Udayana University, Denpasar, Indonesia (2004).

Once, he occupied the English Department Secretary, The vice Dean responsible for Administration and Finance, the chairman of Doctoral Program of Linguistics, Udayana University, and his current position is the chairman of the Faculty Senate. His research interests are Semantics and Psycholinguistics, and he has published several various books dealing with Balinese Verbs, Semantics, Micro linguistics and Indonesia language for International students.

Prof. Sudipa published the article The Development of Syllabus and Lesson Plan Based on English for Occupational Purposes, London: International Journal of Psychosocial Rehabilitation, United Kingdom, 2020. Ngaba and makta of Balinese action verbs, How to map their meanings, Center for Promoting Ideas (CPI), USA, 2019.

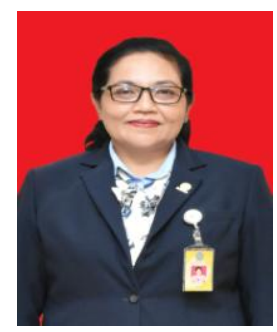

Made Sri Satyawati is a lecturer at the Indonesian Department, Faculty of Humanities, Udayana University, Bali, Indonesia. She obtained her Master Degree in Linguistics from Padjadjaran University, Bandung, Indonesia, in 1999, and she got her Doctorate Degree in Linguistics from Udayana University in 2010. Her research interest is linguistics, and she has conducted some research on syntax, typology, and semantics. Her publications involve studies on the Indonesian language and some local languages in Eastern Indonesia. She has supervised many bachelor papers, theses and doctorate dissertations. She has also participated as guest and invited speaker in a number of national and international seminars. 


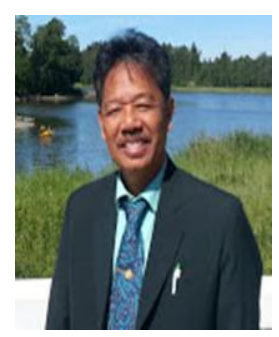

I Made Rajeg is a senior lecturer in linguistics at the Faculty of Arts Udayana University. His research interests include lexical semantics, corpus linguistics, conceptual metaphors, and discourse. His publications can be tracked at Udayana Networking and the Google Scholar: https://udayananetworking.unud.ac.id/lecturer/publication/1817-i-made-rajeg https://scholar.google.com/citations?hl=en\&user=IzMPIWUAAAAJ. 